\title{
MAKALAH ILMIAH
}

\section{GEOKIMIA REGIONAL PULAU SUMATERA CONTO ENDAPAN SUNGAI AKTIF FRAKSI -80 MESH}

\author{
Oleh \\ Sabtanto Joko Suprapto \\ Kelompok Program Penelitian Konservasi - Pusat Sumber Daya Geologi
}

SARI

Penyelidikan geokimia dengan metode analisis kandungan unsur conto endapan sungai aktif -80 mesh merupakan salah satu fase awal eksplorasi terutama untuk menemukan endapan mineral logam. Cebakan bahan galian logam, baik yang sudah tersingkap maupun masih berada di bawah permukaan dapat terungkap pada data geokimia yang dihasilkan. Selain dapat menentukan keberadaan endapan bahan galian, sebaran unsur contoh endapan sungai dapat dipergunakan untuk menentukan kondisi lingkungan dari suatu wilayah.

Sumatera dengan tataan geologi yang komplek dan merupakan jalur metalogenik potensial terbentuknya endapan logam, menghasilkan rona geokimia yang sangat bervariasi dan menarik. Data geokimia regional yang tertuang dalam bentuk peta sebaran unsur menyajikan informasi awal yang penting tentang indikasi mineralisasi untuk ditindak lanjuti dengan penyelidikan lebih rinci.

\section{ABSTRACT}

Geochemical investigation by means the method of analysis through -80 mesh of active stream sediment samples is one of early phase exploration in finding out metallic mineral deposit. Metallic mineral deposit either being cropped out in the surface or subsurface, it can be revealed in geochemical output data. Besides that of determination of the availability of mineral deposits, elements distribution of stream sediment samples can be used to determine environmental condition of an area in relation with.

Sumatra with its complex geologic setting and forming that of a potential metallogenic line so as to the formation of metallic deposits, resulted in very interesting and many variation to that of geochemical performances. Projection of regional geochemistry data in the form of elements distribution maps represent important initial information about mineralization indications to be followed by the detail investigation.

\section{PENDAHULUAN}

Sumatera merupakan pulau besar yang berada di ujung barat Indonesia mempunyai bentangalam memanjang di bagian barat dominan berupa pegunungan, dikenal dengan Bukit Barisan. Sementara di bagian timur berupa perbukitan rendah dan dataran. Batuan gunungapi mendominasi daerah Bukit Barisan, sedangkan di daerah bagian timur didominasi batuan sedimen.

Eksplorasi mineral di Sumatera (Stephenson, 1982 dalam Carlile dan Mitchell, 1994) telah menggambarkan kegiatan pencarian mineral di Sumatera oleh Belanda pada tahun 1900-1945 yang menemukan cebakan-cebakan sekala relatif kecil. Penyelidikan geokimia telah dilakukan setempat-setempat pada daerah prospek mineral. Penyelidikan geokimia conto endapan sungai fraksi -80 mesh secara sistematik oleh Pemerintah Indonesia di Sumatera merupakan awal dari target penyelidikan yang akan mencakup seluruh wilayah daratan Indonesia.

Pengambilan conto geokimia dilakukan oleh Direktorat Sumberdaya Mineral dalam rangka pemetaan geokimia Indonesia secara bersistem sekala 1:250.000. Kegiatan tersebut ditujukan untuk penyediaan data dasar geokimia. Pengambilan conto di Sumatera dilakukan pada tahun 1975 - 1993. Dalam tulisan ini menampilkan digitasi dan pengolahan data yang belum sempat dilakukan dari hasil pengambilan conto tersebut. 
Pemetaan geokimia dilakukan dengan cara pengambilan conto endapan sungai fraksi -80 mesh pada cabang-cabang sungai aktif (Gambar 1). Sebanyak 22.181 conto yang telah terkumpul mewakili daerah penyelidikan seluas $431.800 \mathrm{~km}^{2}$ atau kerapatan rata-rata setiap conto mewakili daerah seluas $19,46 \mathrm{~km}^{2}$.

Fraksi berukuran -80 mesh dari endapan sungai ini dianalisis dengan metode Spektrometri Serapan Atom (AAS) untuk 15 unsur yaitu $\mathrm{Cu}, \mathrm{Pb}, \mathrm{Zn}, \mathrm{Mn}, \mathrm{Fe}, \mathrm{Ag}, \mathrm{Li}, \mathrm{K}, \mathrm{Co}$, $\mathrm{Ni}$, dan $\mathrm{Cr}$. Penentuan kadar unsur $\mathrm{Cu}, \mathrm{Pb}, \mathrm{Zn}$, $\mathrm{Co}, \mathrm{Ni}, \mathrm{Mn}$ dan Ag dengan AAS dilakukan setelah peleburan menggunakan asam nitrat panas. Li, K, Cr dan Fe ditentukan dengan AAS setelah dilakukan peleburan menggunakan asam perkhlorat/hidrofluorat panas. Unsur As, $\mathrm{Sn}, \mathrm{W}$ dan Mo dianalisis dengan metode kolorimetri. Analisis dilakukan di Laboratorium Kimia Mineral yang berada di Direktorat Sumber Daya Mineral, yang saat ini berubah nama menjadi Pusat Sumber Daya Geologi.

Penyelidikan geokimia bersistem untuk menyediakan data dasar, diharapkan dapat menggambarkan kondisi sebaran semua unsur. Akan tetapi mengingat ketersediaan beaya yang ada, maka hanya dapat dianalisis 15 unsur.

Geokimia regional selain dimaksudkan untuk memberikan petunjuk awal potensi dan keberadaan cebakan mineral berdasarkan gambaran anomali geokimia, dapat ditafsirkan juga antara lain dengan sasaran untuk memberikan petunjuk tentang kondisi lingkungan.

\section{GEOLOGI DAN MINERALISASI}

Pulau Sumatera dilewati oleh tiga busur metalogenik (Gambar 2). Selain batuan penyusun yang mempunyai perbedaan, di antara ketiga busur tersebut juga terdapat perbedaan tipe cebakan mineral logam yang terbentuk.

\section{Busur Sumatera- Meratus (Kapur Tengah- Akhir)}

Busur kontinen memanjang pada ujung bagian selatan Paparan Sunda dari utara Sumatera melewati ujung timur Jawa Barat menerus ke arah timur Kalimantan.

Paparan Sunda menjadi busur kontinen tunggal pada Akhir Trias atau Awal Yura, pada Trias dan kemungkinan Awal Yura terjadi tumbukan sepanjang di lepas pantai timur laut Sumatera ke arah Kalimantan, dan kemungkinan melewati bagian tengah Sumatera (Hamilton, 1979; Hutchison, 1989; Mitchell, 1992, dalam Carlile dan Mitchell, 1994). Tumbukan secara langsung maupun tidak langsung menghasilkan jalur kaya timah di Asia Tenggara.

Sejak Yura Tengah sampai Akhir Kapur, tepian selatan Paparan Sunda kemungkinan merupakan tepi kontinen yang pasif, di Sumatera ke arah barat dan Kalimantan ke arah utara, pada Akhir Kapur terjadi perputaran ke arah berlawanan jarum jam pada bagian timur Paparan Sunda dan berarah jarum jam pada bagian barat Paparan Sunda terhadap posisi pada saat ini.

Batuan oseanik berupa Grup Woyla pada bagian barat Sumatera merupakan hasil proses pengangkatan ke arah selatan pada tepi kontinen dari Paparan Sunda. Hal ini kemungkinan bahwa pada Akhir dari Awal Kapur, busur batuan basa berarah utara mengalami tumbukan, terdapat asosiasi ofiolit, dan terangkat menempati pada bagian dari tepian selatan Paparan Sunda yang pasif, membentuk Grup Woyla pada bagian utara Sumatera, batuan yang ekuivalen terdapat pada bagian barat Sumatera bagian selatan, batuan ofiolit di Jawa bagian baratdaya, dan ofiolit Meratus dan Formasi Alino di Kalimantan bagian tenggara.

Busur magmatik mulai mengalami pembalikan proses tektonik setelah pembentukan Kelompok Woyla. Penunjaman ke arah utara menyebabkan pembentukan busur magmatik pada Awal Kapur sampai Akhir Kapur yang melampar melewati Sumatera dan Laut Jawa, terobosan-terobosan berasosiasi dengan kelompok batuan volkanik Manunggal di Pegunungan Meratus, di Sumatera, termasuk pluton Ulai, Batolit Manunggal dan Batolit Sikuleh. Intrusi-intrusi tersebut umumnya menerobos Woyla, akan tetapi di Jalur Bukit Barisan Sumatera Selatan intrusi granit secara struktural menempati bagian lebih rendah, pada Awal Mesozoik atau batuan lebih tua dari batuan dasar kontinen.

Pada busur ini temuan adanya mineralisasi kurang, hal ini kemungkinan akibat dari pengangkatan dan erosi yang sangat intensif pada jaman Tersier. Temuan adanya mineralisasi emas kurang 1\% dari sumber daya emas di Indonesia, serta tembaga yang sangat terbatas. Di Sumatera, terbentuk beberapa mineralisasi berupa cebakan-cebakan skarn bijih besi dan logam dasar dalam dimensi kecil, sebagian mengandung emas dan perak, dan 
emas-tembaga dengan rasio perbandingan $\mathrm{Ag}$ : Au rendah.

\section{Busur Sunda-banda (Neogen)}

Busur Sunda-Banda paling panjang di Indonesia, melampar dari utara Sumatera melewati Jawa ke arah timur dari Damar. Segmen barat terdiri dari Sumatera, Jawa Barat dan sebagian Jawa Tengah, dan terbentuk pada tepian selatan Paparan Sunda, bagian timur dari Jawa Tengah ditafsirkan sebagai busur kepulauan terbentuk pada kontinen yang tipis atau kerak intermediet.

Tektonik Paleogen, dan diikuti tektonik Akhir Kapur dimana kegiatan volkanisme di Busur Sumatera-Meratus berakhir. Tepi Kontinen posisi pasif dari Paparan Sunda pada Akhir Eosen telah melampar ke arah Sumatera, di mana intrusi kalk-alkali terjadi dengan umur antara 52 sampai $57 \mathrm{Ma}$, dan kemungkinan lebih muda menggambarkan adanya penunjaman secara lambat ke arah utara pada Awal sampai pertengahan Eosen.

Deformasi bersifat kompresif di lepas pantai Sumatera bagian barat, dan berakhirnya penunjaman Paleogen, merupakan gambaran saat terbentuknya ofiolit pada bagian utara dan busur kepulauan yang bertepatan dengan terbentuknya ofiolit Oligosen di Jalur IndoBurma, dan juga dengan Formasi batuan bancuh dengan fragmen ofiolit pada kepulauan di sebelah barat Sumatera. Di bagian timur Sumatera, ofiolit dan batuan Paleogen, termasuk basal di Jawa, merupakan bagian dari margin Sunda sebelum Akhir Oligosen.

Pada Akhir Oligosen sampai Akhir Miosen, busur magmatik melampar luas pada sebagian besar Sumatera, membentuk formasi yang oleh Van Bemmelen (1949) disebut Andesit Tua. Busur ini secara stratigrafis setempat terpisah dari batuan yang lebih muda yaitu batuan yang lebih muda dari Neogen, yang dicirikan oleh batuan endapan laut, termasuk di dalamnya batulumpur. Belum ada umur dari pengendapan mineral yang dapat untuk dikorelasikan dengan busur Tersier tengah tersebut, posisinya bersamaan dengan busur Neogen.

Busur andesitik berumur Miosen dengan pelamparan yang sama dengan volkanik Kuarter, melampar sepanjang Bukit Barisan dan menerus ke Jawa dan bagian barat dari Busur Banda sampai Damar. Di luar sebaran tersebut, ke arah timur, hanya dijumpai pulau pulau dengan endapan volkanik Kuarter, dan tidak didapatkan data bahwa pada saat Neogen melampar sampai daerah tersebut. Batuan magmatik pada busur tersebut dominant batuan eruptif, termasuk juga batuan intrusi berumur 12 dan 13 Ma di Sumatera dan intrusi di Jawa. Tidak dijumpai batolit dalam ukuran besar pada Neogen. Riolit dan ignimbrit riolitik berumur Kuarter dijumpai di Sumatera dan Jawa.

Di Sumatera, batuan gunungapi dominan terbentuk pada lingkungan darat dan umumnya menumpang pada batuan berumur Miosen Awal berupa batuan gunungapi, batulumpur, dan batuan dasar berumur Miosen dan Paleozoik termasuk juga batuan ofiolit Mesozoik Akhir dari Grop Woyla, serta batuan plutonik busur magmatik Kapur Akhir. Pengangkatan pada saat volkanisme aktif pada Kenozoik Akhir ditandai oleh adanya batuan lumpur yang terbentuk pada lingkungan laut menempati ketinggian sampai 1100 meter di Bukit Barisan.

Busur ini berpotensi terjadinya mineralisasi, dimana mineralisasi emas dan tembaga yang terbentuk merupakan 20\% dari potensi emas, dan $14 \%$ dari potensi tembaga di Indonesia. Segmen kontinen bagian barat dicirikan oleh banyak dijumpainya cebakan epitermal sistem urat tipe sulfidasi rendah seperti di Pasaman, Lebong Tandai, Musirawas, Lampung, Pongkor dan Cibaliung. Cebakan mineralisasi logam Zn, $\mathrm{Pb}, \mathrm{Cu}$, dan Ag dengan batuan induk sedimen dijumpai di Dairi. Cebakan Cu-Au porfiri terdapat di Daerah Ise-ise dan Tengkereng di Aceh Tenggara serta Batuhijau, Sumbawa. Sementara cebakan tipe sulfida masif volkanogenik dijumpai di Wetar dan Haruku.

\section{Busur Aceh (Neogen)}

Busur Aceh berbatasan dengan bagian utara dari Sumatera. Stephenson dkk (1982) menggambarkan penunjaman di lepas pantai bagian utara Sumatera dimana pada daerah ini endapan gunungapi muda berhubungan dengan yang terdapat pada bagian daratan. Tunjaman tersebut kemungkinan juga aktif pada awal Miosen Tengah, diduga bahwa penunjaman ke arah selatan dari Cekungan Mergui yang bersifat oseanik menunjam di bawah batuan dasar bagian utara Sumatra dari Paparan Sunda.

Meskipun sedikit penyelidikan yang dilakukan, Busur Aceh dengan jelas dapat dibedakan dengan bagian barat dari Busur Sunda-Banda, serta dicirikan dengan terdapatnya tembagamolibdenum porfiri (Van Leeuwen dkk., 1987 dalam Carlile dan Mitchell, 1996) dan lebih dominannya mineralisasi epitermal sulfidasi tinggi dibandingkan sulfidasi rendah. 


\section{GEOKIMIA}

Penentuan kelas sebaran unsur unsur logam di Pulau Sumatera didasarkan pada pembagian secara persentil. Kelas terakhir dengan harga tinggi sebagai nilai anomali umumnya merupakan isarat adanya pemineralan. Pembahasan geokimia berikut, dibatasi pada hasil analisis unsur tunggal.

\section{Perak (Ag)}

Hasil analisis kimia perak yang harganya lebih besar dari batas deteksi jumlahnya sangat terbatas. Sebagian besar lebih kecil atau sama dengan harga batas deteksi. Harga berkisar dari bawah batas deteksi sampai dengan 800 ppm (Tabel 1). Kelompok harga tinggi terdapat di baratdaya Danau Toba, Bengkulu dan di Lampung.

Walaupun nilai perak yang berada di atas harga batas deteksi sangat jarang, namun beberapa kelompok peninggian harga perak yang tergambar pada citra geokimia (Gambar 3 dan 4A) berkaitan dengan daerah mineralisasi perak dan emas.

\section{Arsen (As)}

Kadar arsen berkisar dari 0,1- 600 ppm (Tabel 1). Pola peninggian arsen di bagian selatan Sumatera memanjang sejajar Bukit Barisan, dan relatif menyebar luas di bagian selatan Aceh.

Pola peninggian arsen membentuk kelurusan di sepanjang perbukitan Barisan pada beberapa lokasi berkaitan dengan keberadaan cebakan mineral logam, terutama emas dan perak (Gambar 3 dan 4B). Peninggian kandungan arsen secara signifikan di Aceh, yaitu di Daerah Lumut dan sekitarnya, Kabupaten Aceh Timur terkait dengan dijumpainya cebakan emas epitermal tipe Carlin.

Anomali arsen pada beberapa lokasi yang lain dimana data keterdapatan logam tidak dijumpai, dapat memberikan peluang bahwa anomali tersebut kemungkinan merupakan indikasi adanya cebakan emas dan perak.

\section{Kobal (Co)}

Kadar kobal berkisar dari 1 ppm sampai dengan 370 ppm (Tabel 1). Harga tertinggi 370 ppm berada pada daerah Aceh. Sebaran umum dari kobal mirip dengan $\mathrm{Ni}$ dan $\mathrm{Cr}$, beberapa nilai tinggi terdapat di sepanjang Bukit Barisan, berasosiasi ultramafik dan basaltik (3 dan Gambar 4C).

\section{Khromium (Cr)}

Kadar khrom dari bawah batas deteksi 3 ppm sampai dengan 40.000 ppm (Tabel 1). Harga tertinggi 40.000 ppm berada di Aceh (Gambar 4D). Sebaran harga tinggi $\mathrm{Cr}$ berasosiasi dengan batuan ultramafik. Anomali signifikan kemungkinan berasosiasi dengan mineralisasi khrom.

\section{Tembaga (Cu)}

Nilai tembaga berkisar dari 2 ppm sampai dengan 2.131 ppm. Harga tinggi tembaga mengelompok di beberapa lokasi di Aceh, Sumatera Barat dan bengkulu. Anomali tembaga pada daerah tersebut terkait dengan adanya keterdapatannya cebakan tembaga seperti di Tangse, Tengkereng, Ise-ise dan barat Kerinci (Gambar 3 \& 4E).

\section{Besi (Fe)}

Kandungan besi $0,007 \%$ sampai $79,6 \%$. Anomali besi pada beberapa lokasi berkaitan dengan adanya mineralisasi besi. Pola sebaran harga Fe mempunyai kecenderungan yang meninggi pada daerah dengan harga Sn rendah, atau sebaliknya cenderung rendah pada daerah peninggian harga Sn (Gambar 3 \& 4F).

\section{Kalium (K)}

Kandungan kalium berkisar dari 47 sampai dengan 75.600 ppm. Daerah peninggian kalium berada di sepanjang Bukit Barisan bagian tengah dan utara. Sebaran unsur Kalium dan Litium mempunyai pola yang hampir sama. Harga kandungan unsur kalium cenderung rendah pada daerah dataran timur Sumatera, kecuali di Daerah Lubuk Pakam sampai Kisaran, di Provinsi Sumatera Utara mempunyai harga tinggi (Gambar 5A).

\section{Litium (Li)}

Li mempunyai kisaran harga dari 1 ppm sampai dengan 214 ppm. Harga tinggi litium erat kaitannya dengan batuan terobosan granitoid dan batuan malihan.

Litium relatif tinggi di Daerah Aceh dimana dijumpai batuan malihan yang luas, dan setempat-setempat di sepanjang perbukitan 
Barisan. Harga litium rendah terdapat di daerah morfologi rendah bagian timur Sumatera. Beberapa kelurusan sebaran harga litium dengan kandungan relatif tinggi dengan arah baratdaya-timurlaut memotong Pulau Sumatera seperti di Daerah Tembesi, kemungkinan merupakan indikasi adanya sturktur geologi dan adanya batuan granitoid (Gambar 5B).

\section{Mangan (Mn)}

Kadar mangan 10 ppm sampai dengan 20.000 ppm dengan rata-rata aritmatik 496,21 ppm. Harga tinggi sebaran mangan pada beberapa lokasi di sepanjang perbukitan Barisan berasosiasi dengan keterdapatan mineralisasi emas (Gambar 3 dan 5C). Citra geokimia mangan dengan nilai rendah berada di daerah morfologi rendah bagian timur Pulau Sumatera.

Kelurusan harga kandungan mangan relatif agak tinggi di daerah timur Sumatera terdapat memanjang pada zona patahan Muara Tembesi dan sekitarnya, kemungkinan sebagai akibat kontrol dari struktur geologi.

\section{Molibdenum (Mo)}

Molibdenum berkisar dari 1 ppm sampai dengan 980 ppm. Peninggian sebaran unsur Mo terdapat di Kampar berasosiasi dengan Sn, dan setempat-setempat di daerah Lampung, Bengkulu dan selatan Danau Toba (Gambar 3D). Sebaran Mo dengan nilai tinggi merupakan indikasi kemungkinan adanya mineralisasi molibdenum dan logam ikutannya pada lingkungan mesotermal.

\section{Nikel (Ni)}

Kadar nikel berkisar dari 1 ppm sampai dengan 5.800 ppm. Harga tinggi nikel terdapat di beberapa tempat di perbukitan Barisan (Gambar 5E). Pola sebaran umum Ni mirip dengan sebaran $\mathrm{Cr}$ dan Co, di mana beberapa harga tinggi berkaitan dengan keberadaan batuan ultrabasa.

\section{Timbal $(\mathbf{P b})$}

Hasil analisis timbal mempunyai kisaran dari 2 ppm sampai dengan 9.011 ppm, dengan ratarata 22,05 ppm. Peninggian timbal pada bagian barat Sumatera mulai dari Lampung sampai Aceh umumnya berasosiasi dengan adanya mineralisasi sulfida. Timbal dengan kadar rendah mempunyai sebaran menerus pada daerah dataran di Sumatera Selatan sampai Riau (Gambar 5F).

\section{Timah (Sn)}

Kadar timah 7 ppm sampai dengan 548 ppm. Pola sebaran peninggian timah bertolak belakang dengan harga kadar besi. Pada daerah dengan kadar timah tinggi kandungan besi cenderung rendah, atau pada daerah dengan sebaran timah nilai rendah terdapat sebaran besi dengan nilai tinggi.

Peninggian timah terdapat di Daerah Riau sampai Jambi merupakan indikasi adanya mineralisasi timah (Gambar 3 dan 6A).

\section{Wolfram (W)}

Kadar wolfram mulai dari batas nilai deteksi sampai dengan 1.250 ppm. Kandungan wolfram yang sebagian besar rendah, atau di bawah nilai batas deteksi analisis, mempunyai sebaran dengan pola tidak teratur. Kadar tinggi dijumpai di sekitar Danau Toba. Peninggian harga tersebut kemungkinan merupakan cerminan adanya mineralisasi wolfram (Gambar 6B).

\section{Seng (Zn)}

Kandungan seng 2 ppm sampai dengan 6.000 ppm, rata-rata 62,1 ppm. Pola sebaran Zn mirip dengan pola sebaran $\mathrm{Cu}$, dan $\mathrm{Pb}$. Hal ini berkaitan dengan adanya mineralisasi sulfida pada daerah peninggian unsur-unsur tersebut (Gambar 3 dan 6C).

Kelurusan harga kandungan seng relatif agak tinggi di daerah timur Sumatera terdapat memanjang pada zona patahan Muara Tembesi dan sekitarnya. Pola kelurusan tersebut merupakan indikasi adanya struktur geologi (Gambar 3 dan 6C).

\section{PEMBAHASAN}

Geokimia regional endapan sungai menunjukkan adanya beberapa pola sebaran unsur logam di Pulau Sumatera. Pola sebaran unsur dengan kandungan tinggi umumnya berasosiasi dengan mineralisasi. Sebaran unsur dengan kandungan rendah juga merupakan indikasi yang menarik dari sisi kegeologian.

Batuan dari cekungan sedimenter yang terdapat melampar dari Sumatera Selatan 
sampai Riau dicirikan dengan nilai kandungan logam rendah, kecuali unsur Sn yang cenderung tinggi di daerah Riau. Hal ini memberikan gambaran akan adanya dua mandala geokimia di Pulau Sumatera, yaitu mandala barat menempati sepanjang Bukit Barisan dengan penyusun utama berupa batuan gunungapi dan mandala timur yang menempati daerah morfologi rendah dengan batuan penyusun sedimenter.

Pada daerah sepanjang perbukitan Barisan terdapat beberapa anomali signifikan dari beberapa unsur logam. Anomali pada bagian timur Sumatera terdapat memanjang baratdaya-timur laut di Daerah Muara Tembesi, pola tersebut kemungkinan akibat kontrol adanya patahan Muara Tembesi yang memotong Pulau Sumatera.

Pola sebaran antara Sn dan Fe mempunyai kecenderungan nilai yang saling bertolak belakang. Pada daerah Sn tinggi, kadar Fe rendah, demikian juga sebaliknya. Pola tersebut dimana peninggian Sn mencerminkan adanya mineralisasi timah dan peninggian $\mathrm{Fe}$ menunjukkan adanya mineralisasi besi, juga merupakan cerminan batuan yang terdapat pada daerah tersebut. Pada daerah Sn tinggi terdapat granit tipe $S$ (tipe ilmenit) dengan kandungan besi relatif rendah, pada daerah dengan kandungan $\mathrm{Fe}$ tinggi terdapat kemungkinan dijumpainya granit tipe I (tipe magnetit), dengan kandungan magnetit (besi) lebih tinggi. Pola peninggian Sn terdapat dari Daerah Riau sampai Jambi. Peninggian Fe terdapat di beberapa lokasi di sepanjang Bukit Barisan dan meluas di Daerah Bengkulu sampai Lampung.

Daerah-daerah geokimia dengan nilai $\mathrm{K}$ dan atau Li meninggi yang merupakan anomali, mencirikan adanya granitoid, dan di beberapa lokasi berasosiasi dengan mineralisasi logam, serta peninggian beberapa jenis unsur. Peninggian kadar $\mathrm{K}$ tanpa disertai peninggian harga Li dijumpai memanjang dari Daerah Lubuk Pakam sampai Kisaran, di Provinsi Sumatera Utara, kemungkinan merupakan akibat kontaminasi dari kegiatan pertanian.

Daerah dengan anomali berupa peninggian unsur $\mathrm{Ag}, \mathrm{As}, \mathrm{Cu}, \mathrm{Pb}, \mathrm{Zn}, \mathrm{Ag}, \mathrm{Mn}$ dan Fe pada di beberapa lokasi, sebagian terdapat bersamaan dengan dijumpainya mineralisasi sulfida dan sebagian mineralisasi emas (Gambar 3), anomali pada daerah lainnya di mana tidak ada data keterdapatan mineralisasi logam dapat ditafsirkan juga sebagai cerminan adanya mineralisasi logam. Peninggian kandungan $\mathrm{Ni}, \mathrm{Cr}$ dan $\mathrm{Co}$ di beberapa lokasi di
Bukit Barisan terdapat pada daerah dengan batuan jenis ultrabasa.

Garis geokimia digambarkan oleh penjajaran unsur-unsur yang bernilai tinggi, penjajaran nilai rendah, atau antara nilai tinggi dan rendah yang membentuk batas tegas dan lurus. Hal tersebut dapat ditafsirkan berhubungan dengan pola sebaran batuan, intrusi atau struktur, khususnya patahan. Beberapa kelurusan geokimia Pulau Sumatera dapat di jumpai memanjang arah perbukitan Barisan dari Lampung sampai Aceh. Kelurusan-keluruan geokimia dapat dijumpai juga dengan arah baratdaya-timurlaut memotong Pulau Sumatera.

Geokimia merupakan cerminan kondisi permukaan maupun bawah permukaan, dapat sebagai dasar pertimbangan awal dalam pengembangan suatu wilayah atau kawasan, serta dapat mengungkap potensi bahan galian dan mineralisasi di permukaan dan bawah permukaan.

Sebagai data dasar, geokimia sebaran unsur contoh endapan sungai aktif fraksi -80 mesh dapat dipergunakan untuk beberapa keperluan, di antaranya pada kegiatan eksplorasi awal sebagai indikator adanya mineralisasi logam. Aspek lingkungan geokimia, data sebaran unsur dapat digunakan sebagai penentuan kondisi rona awal dan akhir terutama pada lingkungan wilayah pertambangan, seperti arsen dan timbal sebagai unsur yang mempunyai sifat racun pada beberapa lokasi di Sumatera telah menunjukkan rona awal yang tinggi.

Sebagai salah satu dari beberapa metode pada eksplorasi endapan logam primer, metoda geokimia endapan sungai aktif selalu digunakan. Biaya penyelidikan geokimia relatif murah, data yang dihasilkan memberikan isyarat tentang keterdapatan endapan logam dengan tingkat kepastian tinggi, dan dapat mengungkap keberadaan bahan galian yang sudah tersingkap maupun masih berada di bawah permukaan, serta berada jauh di bagian hulu dari lokasi pengambilan conto.

\section{KESIMPULAN}

Geokimia di Pulau Sumatera conto endapan sungai aktif fraksi -80 mesh dengan analisis kandungan unsur Ag, As, Co, Cr, Cu, Fe, K, Li, $\mathrm{Mn}, \mathrm{Ni}, \mathrm{Pb}, \mathrm{Sn}, \mathrm{W}$, Mo dan $\mathrm{Zn}$ dapat memberikan gambaran tentang kondisi geologi, mineralisasi maupun lingkungan geokimia. Analisis kimia conto endapan sungai dapat 


\section{MAKALAH ILMIAH}

untuk mengungkap kondisi geokimia di daerah aliran sungai di bagian hulu dari contoh yang diambil, baik kondisi permukaan maupun bawah permukaan.

Beberapa anomali geokimia terdapat bersamaan dengan keterdapatn mineralisasi logam. Nilai kadar anomali tersebut dapat digunakan untuk korelasi daerah lain dimana tidak dijumpai data mineralisasi logam, sehingga daerah dengan nilai anomali unsur logam dapat ditafsirkan akan adanya mineralisasi logam.

Kondisi geologi dapat tercermin pada pola sebaran unsur, baik kondisi litologi penyusun maupun struktur geologinya. Sebaran unsur potensial sebagai bahan racun dapat diketahui pada sebaran unsur baik berupa rona awal maupun akhir.

\section{Ucapan Terima Kasih}

Terimakasih disampaikan kepada almarhum Bpk. Hasbulah yang telah banyak membantu pada saat kegiatan lapangan, Bpk. Kosim yang telah banyak membantu dalam proses digitasi.

\section{ACUAN}

, 2007. Neraca Sumber Daya Mineral Logam. Pusat Sumber Daya Geologi, Bandung

Carlile, J.C., dan Mitchell, 1994. Magmatic arcs and associated gold and copper mineralization in Indonesia. Journal of Geochemical Exploration, Amsterdam.

Van Bemmelen, RS., 1949. The Geology of Indonesia. Vol. IA. Ist Edition. Govt.Printing Office, The Hague. 


\section{MAKALAH ILMIAH}

Tabel 1. Ringkasan statistik kandungan unsur, satuan dalam ppm kecuali Fe dalam \%

\begin{tabular}{|c|c|c|c|c|c|c|c|}
\hline NO & UNSUR & $\begin{array}{c}\text { JUMLAH } \\
\text { CONTOH }\end{array}$ & MIN & MAKS & $\begin{array}{c}\text { RATA } \\
\text { RATA }\end{array}$ & $\begin{array}{c}\text { STANDAR } \\
\text { DEVIASI }\end{array}$ & $\begin{array}{c}\text { BATAS } \\
\text { DETEKSI }\end{array}$ \\
\hline 1 & $\mathrm{Ag}$ & 22.181 & 0,7 & 800 & 0,87 & 5,41 & 0,5 \\
\hline 2 & $\mathrm{As}$ & 22.181 & 1 & 600 & 3,49 & 8,64 & 1 \\
\hline 3 & $\mathrm{Co}$ & 22.181 & 1 & 370 & 14,02 & 12,09 & 0,5 \\
\hline 4 & $\mathrm{Cr}$ & 22.181 & 3 & 40.000 & 60,94 & 296,91 & 3 \\
\hline 5 & $\mathrm{Cu}$ & 22.181 & 2 & 2131 & 33,99 & 81,01 & 2,5 \\
\hline 6 & $\mathrm{Fe}$ & 22.181 & 0,007 & 79,6 & 5,34 & 4,52 & 50 \\
\hline 7 & $\mathrm{~K}$ & 22.181 & 47 & 75.600 & 10.123 & 8.588 & 40 \\
\hline 8 & $\mathrm{Li}$ & 22.181 & 1 & 214 & 19,59 & 11,94 & 0,5 \\
\hline 9 & $\mathrm{Mn}$ & 22.181 & 10 & 20.000 & 496,21 & 540,88 & 5 \\
\hline 10 & $\mathrm{Mo}$ & 22.181 & 1 & 980 & 1,11 & 6,83 & 0,4 \\
\hline 11 & $\mathrm{Ni}$ & 22.181 & 1 & 5.800 & 22,98 & 97,81 & 0,5 \\
\hline 12 & $\mathrm{~Pb}$ & 22.181 & 2 & 9.011 & 22,05 & 83,48 & 2 \\
\hline 13 & $\mathrm{Sn}$ & 22.181 & 7 & 8.000 & 11,08 & 66,65 & 5 \\
\hline 14 & $\mathrm{~W}$ & 22.181 & 1,7 & 1.250 & 3,72 & 30,16 & 1 \\
\hline 15 & $\mathrm{Zn}$ & 22.181 & 2 & 6.000 & 62,1 & 63,39 & 2 \\
\hline
\end{tabular}

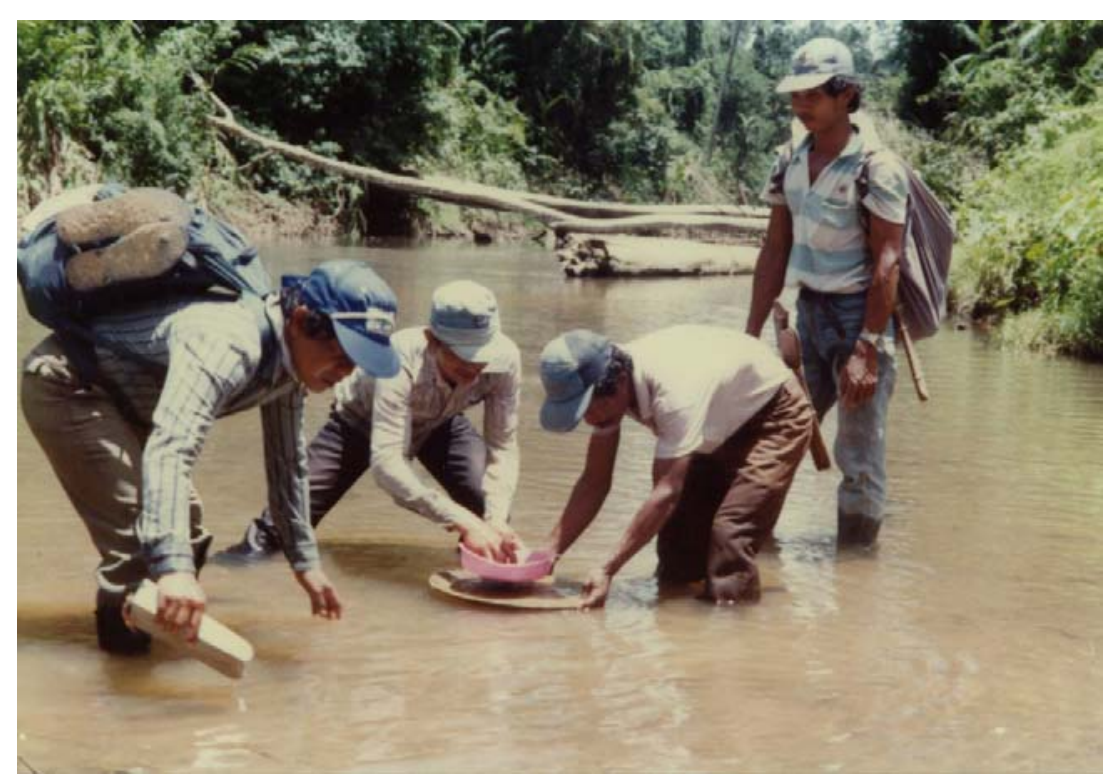

Gambar 1. Pengambilan conto endapan sungai aktif, fraksi -80 mesh, di Lampung tahun 1992 (foto koleksi SJ Suprapto) 


\section{MAKALAH ILMIAH}

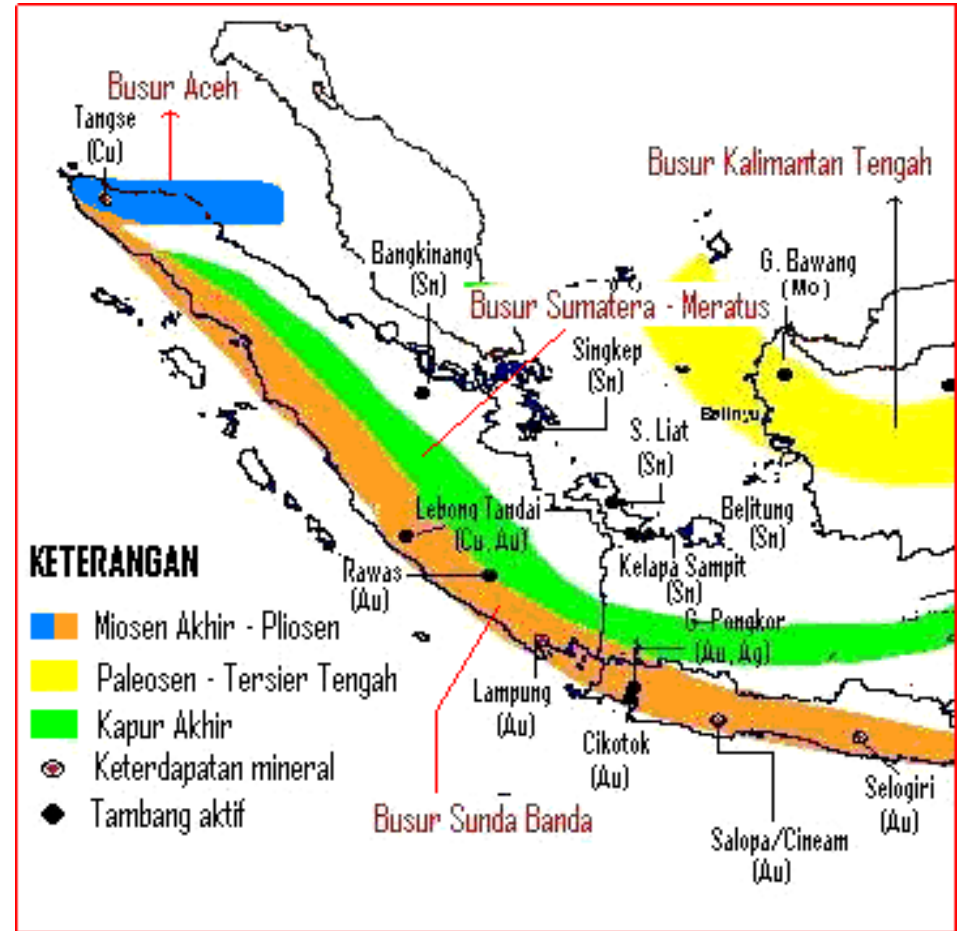

Gambar 2. Peta busur metalogenik Sumatera (modifikasi dari Carlile dan Mitchell, 1994).

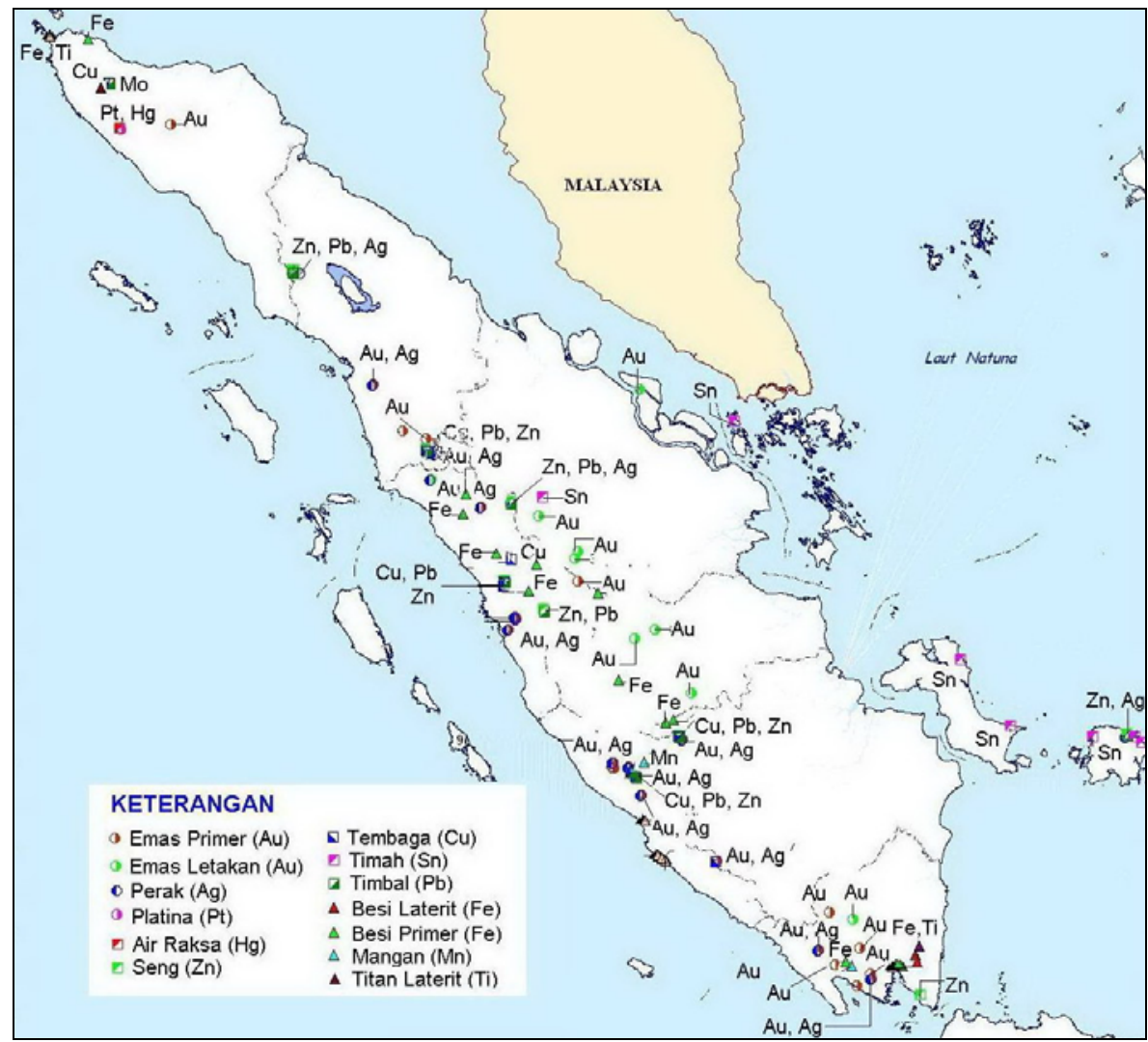

Gambar 3. Lokasi cebakan mineral logam (Pusat Sumber Daya Geologi, 2007) 

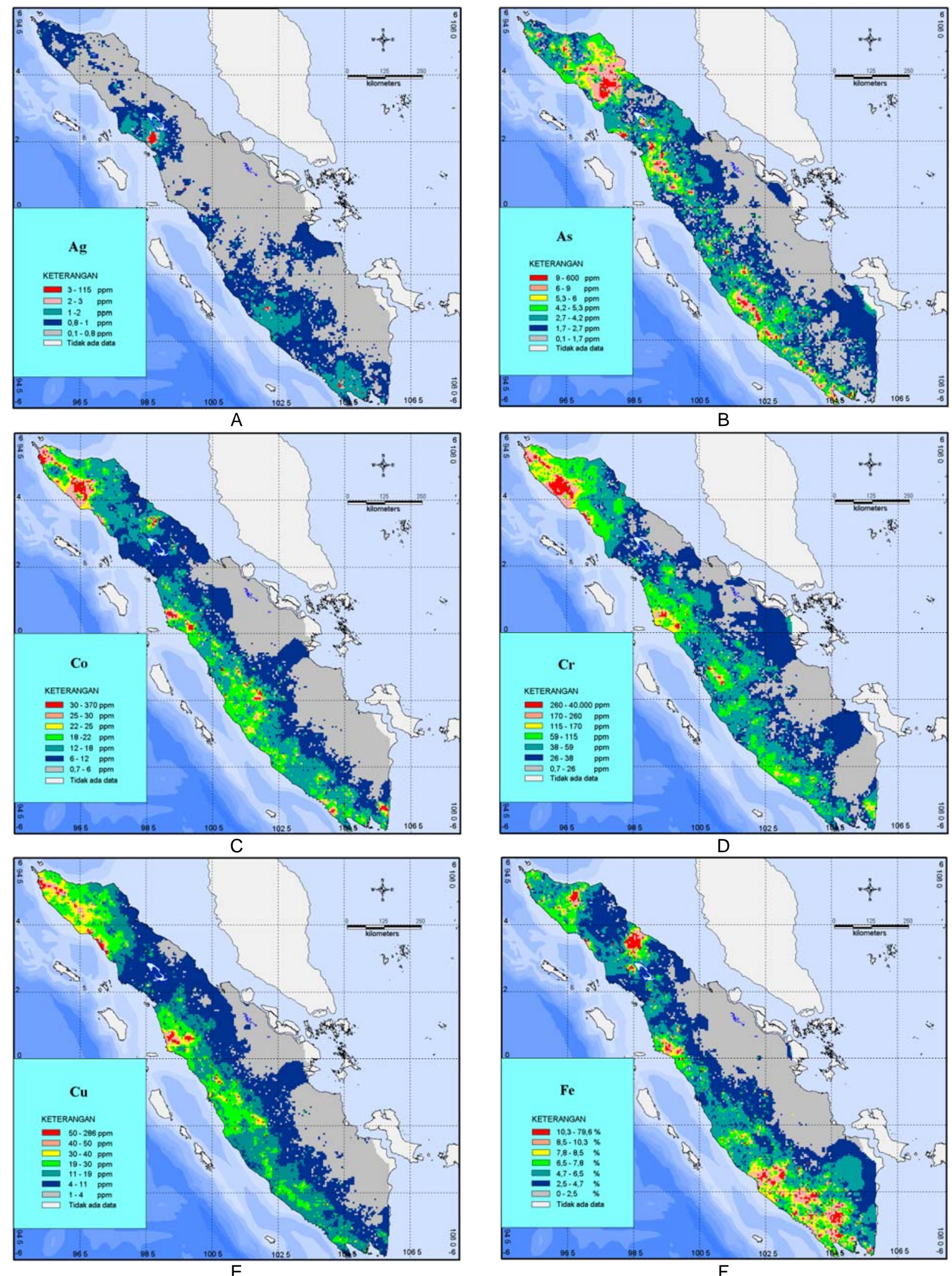

Gambar 4. Peta Sumatera menunjukkan (A) Sebaran unsur perak; (B); Sebaran unsur arsen; (C) Sebaran unsur kobal; (D) sebaran unsur khrom; (E) sebaran unsur tembaga; dan (F) sebaran unsur besi. 


\section{MAKALAH ILMIAH}
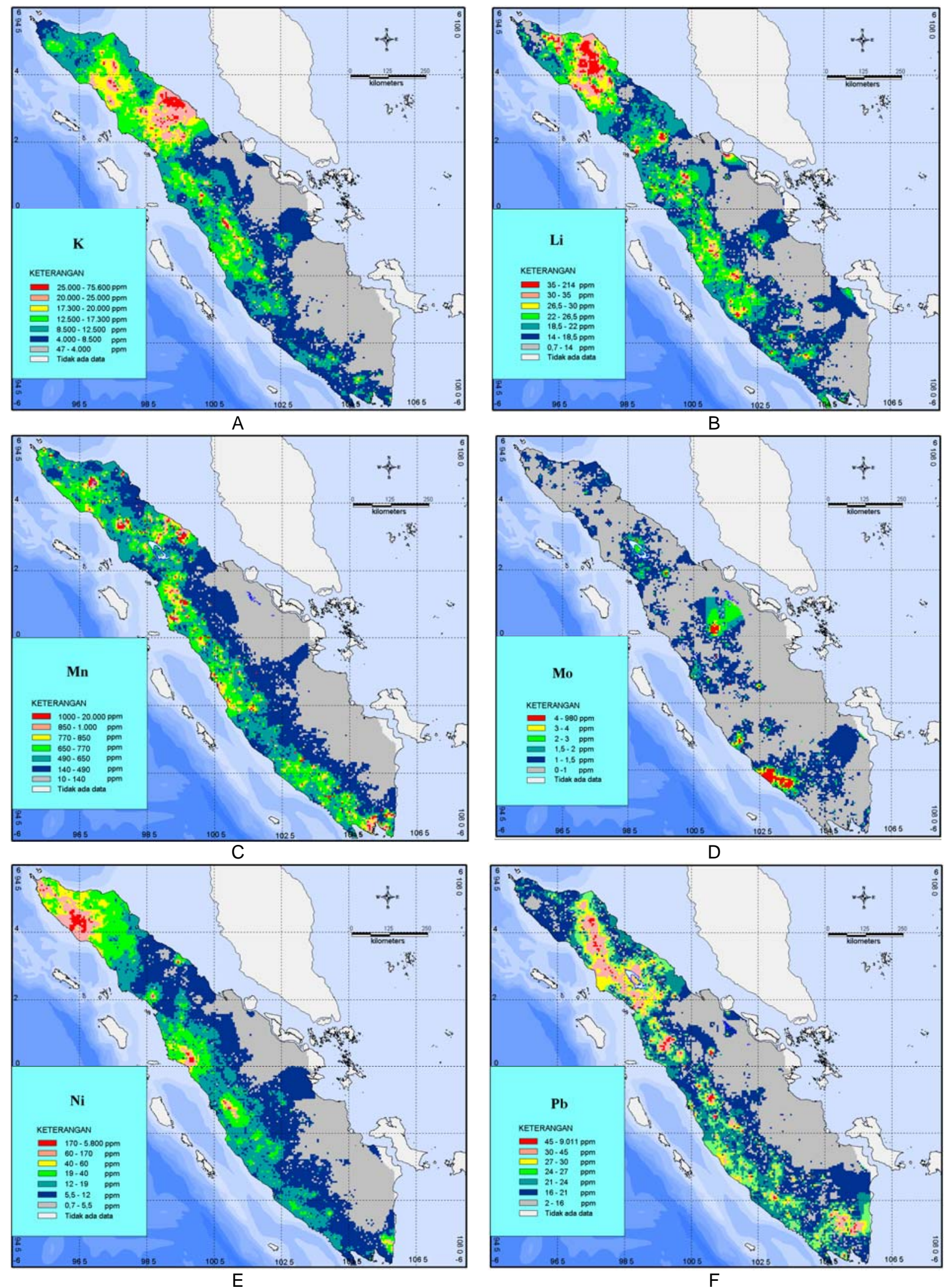

Gambar 5. Peta Sumatera menunjukkan (A) Sebaran unsur kalium; (B) Sebaran unsur litium; (C) Sebaran unsur mangan; (D) sebaran unsur molibdenum; (E) sebaran unsur nikel; dan (F) sebaran unsur timbal. 

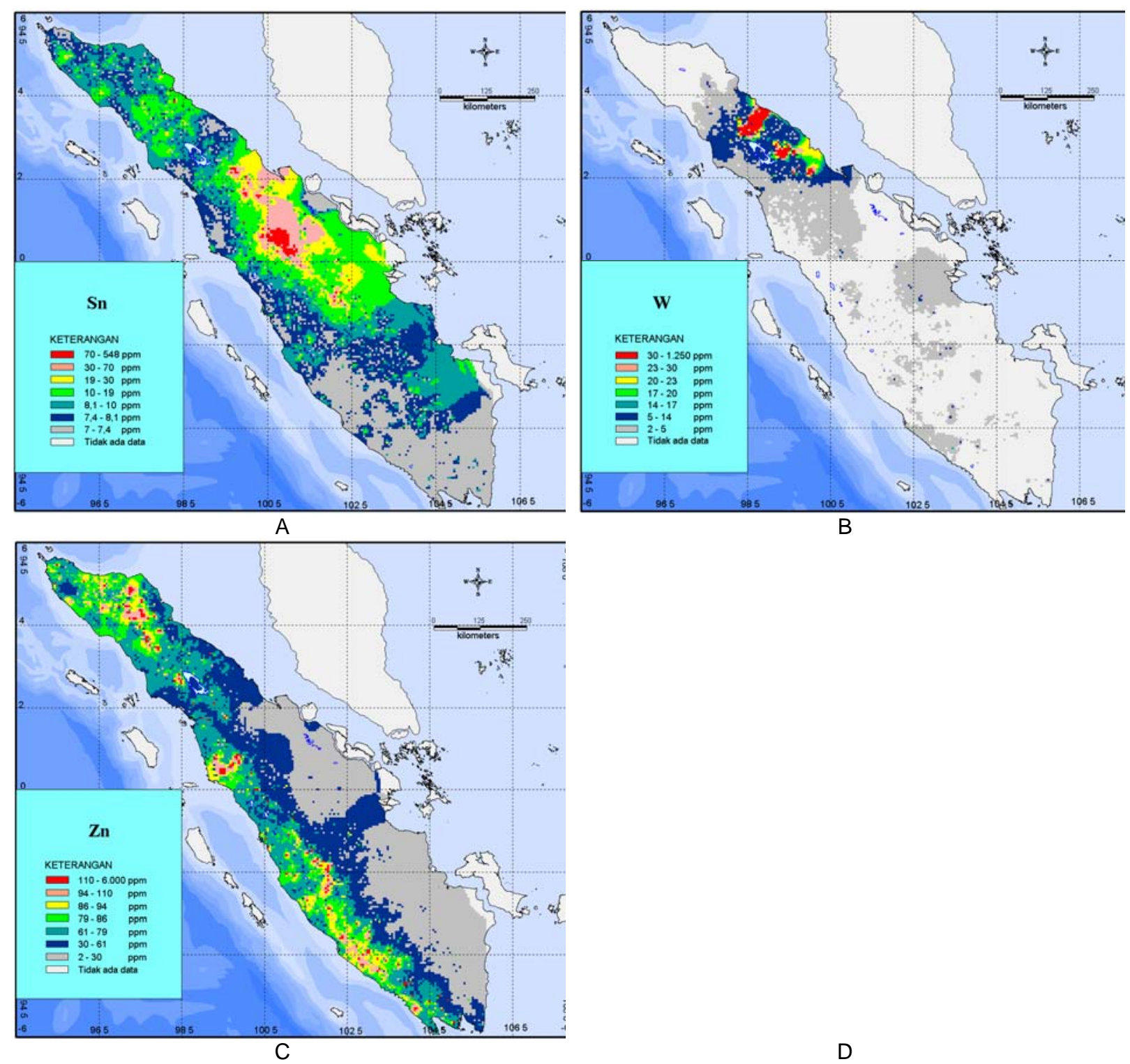

D

Gambar 6. Peta Sumatera menunjukkan (A) Sebaran unsur timah; (B) Sebaran unsur wolfram; (C) Sebaran unsur seng. 